\title{
Progress in electromechanically active polymers: selected papers from EuroEAP 2017 Editorial
}

Jager, Edwin W H; Skov, Anne Ladegaard; Otero, Toribio; Jean-Mistral, Claire

\section{Published in:}

Smart Materials and Structures

Link to article, DOI:

10.1088/1361-665X/aac300

Publication date:

2018

Document Version

Peer reviewed version

Link back to DTU Orbit

Citation (APA):

Jager, E. W. H., Skov, A. L., Otero, T., \& Jean-Mistral, C. (2018). Progress in electromechanically active polymers: selected papers from EuroEAP 2017: Editorial. Smart Materials and Structures, 27(7), 070201070201. https://doi.org/10.1088/1361-665X/aac300

\section{General rights}

Copyright and moral rights for the publications made accessible in the public portal are retained by the authors and/or other copyright owners and it is a condition of accessing publications that users recognise and abide by the legal requirements associated with these rights.

- Users may download and print one copy of any publication from the public portal for the purpose of private study or research.

- You may not further distribute the material or use it for any profit-making activity or commercial gain

- You may freely distribute the URL identifying the publication in the public portal 


\section{Progress in electromechanically active polymers: selected papers from EuroEAP 2017}

Electromechanically active polymers (EAPs) are an interesting new class of smart materials with a wide range of applications such as soft robotics, haptics, and biomedicine amongst many. They can be used as soft actuators, sometimes addressed as artificial muscles, as well as for sensors, and for energy harvesting. Commercial spin-offs based on EAPs have been started focusing on commercializing flexible stretch sensors and dielectric stacks.

Since its start in Pisa in 2010, the EuroEAP society annually organises the International conference on Electromechanically Active Polymer transducers \& artificial muscles ("EuroEAP conference"). The conference has steadily grown and has become a vivid meeting gathering approximately 130 scientists, engineers, students and industry representatives from all over the world. The focus point is information exchange around long poster sessions, including prototype and product demonstrations where even the last session attracts a vivid exchange and discussions. This is interchanged by invited oral presentations of world leading experts and short orals. The 2017 edition was held in Cartagena, Spain, chaired by Prof Toribio Otero.

This focus issue gathers some of the highlights of EuroEAP 2017, as impartially selected by the guest editors (the past, current and coming Chairs of the EuroEAP conference and EuroEAP vice President). The papers cover a wide range of EAP research: chemical sensors, droplet-based electrostatic transducers and multi degree of freedom hydrostatically coupled dielectric elastomer actuators; from EAP microactuators and dielectric stack actuators for micromixers to electroactive textiles; as well as fundamental studies on electromechanical aging and the use non-linear biasing elements for dielectric elastomer actuators.

The international forum that the EuroEAP conferences represents is also displayed in submitted papers in this focus issue, with contributions from groups in Canada, France, Germany, Italy, New Zealand, Spain, Sweden, Switzerland, and the United Kingdom.

The selected papers in this focus issue demonstrate the quality and originality of the conference contributions. In a time where more and more focus is put towards soft robotics, soft interactions with humans in terms of sensors and sustainable energy generation, it is good to see the advances in the EAP technology and to see novel products based on EAPs being commercialized and perceived positively. We thank all participants for their active partaking in the EuroEAP conference and especially the authors of the papers of the focus issue for their relevant articles sharing the progress in EAPs.

We hope to see you at the next EuroEAP conference 5-6 June, 2018 in Valpré Ecully- Lyon, France

Edwin Jager, Linköping University, Sweden, Vice-president of the EuroEAP Society

Anne Ladegaard-Skov, Technical University of Denmark (DTU), Denmark, Chair EuroEAP 2016

Toribio Otero, Technical University of Cartagena, Spain, Chair EuroEAP 2017

Claire Jean Mistral, National Institute of Applied Science - INSA de Lyon, France, Chair EuroEAP 2018 